\title{
Characteristics of a previously undescribed fishery and habitat for Manta alfredi in the Philippines
}

\author{
Jo Marie V. Acebes ${ }^{1,2^{*}}$, Yotam Barr ${ }^{3}$, Jacqueline Marjorie R. Pereda ${ }^{4}$ and Mudjekeewis D. Santos ${ }^{4}$
}

\begin{abstract}
Seven species of mobulid rays occur in the Philippines, six of which, including the Giant Manta Ray (Manta birostris) are caught directly or indirectly. In the Bohol Sea, mobulids have been fished since at least the nineteenth century yet the extent is not well-understood. A second species of manta, Manta alfredi was taxonomically resurrected in 2009 and also only recently been confirmed to occur in the Philippines. This study aimed to identify and describe the presence of and fishery for M. alfredi in a previously unknown area of occurrence in the Philippines. Key informant interviews, observation of catch landings, and tissue sample collection were conducted in a fishing village off Dinagat Island. Based on morphological examination and through DNA barcoding using the mitochondrial DNA CO1 gene of tissue samples it was verified that the species targeted in this area is the reef manta ray, Manta alfredi. Local ecological knowledge of the fishers provided important information on the extent and characteristics of the fishery. This relatively recent ray fishery in the Surigao Strait is the source of mobulids during the off-fishing season in Bohol with fishers from this area transporting and selling their processed catches to Bohol. The description of this fishery and habitat for the reef manta ray in the Surigao Strait is important in the understanding of the status of the species in the Philippines and in designing a management framework.
\end{abstract}

Keywords: Manta alfredi, Mobulid, Habitat, Fishery, DNA barcoding, Local ecological knowledge, Philippines

\section{Introduction}

Mobulid rays or devil rays fall under the Family Mobulidae, represented by two genera, the Manta and Mobula (Couturier, 2012). In the Philippines, seven species of mobulid rays occur: Manta birostris (Walbaum, 1792), Manta alfredi (Krefft, 1868), Mobula japanica (Müller \& Henle, 1841), Mobula thurstoni (Lloyd, 1908), Mobula tarapacana (Philippi, 1892), Mobula kuhlii (Müller \& Henle, 1841) and Mobula eregoodootenke (Bleeker, 1859) (Alava et al., 2015). Six out of these seven species are caught either directly or indirectly (by-catch) in fisheries around the country (Dolar, 1994; Alava et al., 2002; Rayos et al. 2012; Acebes, 2013; Alava et al., 2015). M. birostris has been protected under Philippine laws since 1998 particularly Fisheries Administrative Order (FAO) No. 193

\footnotetext{
*Correspondence: jomacebes@yahoo.com

'BALYENA.ORG, Paseo del Mar, Barangay Pangdan, Jagna, Bohol 6308, Philippines

2Department of Biology, Ateneo de Manila University, Loyola Heights,

Quezon City, Philippines

Full list of author information is available at the end of the article
}

Series of 1998 ("Ban on the taking or catching, selling, purchasing and possessing, transporting and exporting whale sharks and manta rays") of the Department of Agriculture. This legal protection has been expanded under the recently passed 2015 Republic Act 10654 "An act to prevent, deter and eliminate Illegal, Unreported, Unregulated fishing amending Republic Act No. 8550 otherwise known as 'The Philippine Fisheries Code of 1998, and for other purposes, and its Implementing Rules and Regulations (IRR)." Under its Section 102 entitled "Fishing or Taking of Rare, Threatened or Endangered Species" it is stipulated that it shall be unlawful to fish or take, catch, gather, sell, purchase, possess, transport, export, forward or ship out aquatic species listed in Appendix I of the Convention on the International Trade in Endangered Species of Wild Flora and Fauna (CITES), or those categorized by the International Union for Conservation of Nature and Natural Resources (IUCN) as threatened and determined by the Department as such. Furthermore, it shall be unlawful 
to fish, take, catch, gather, sell, purchase, possess, transport, export, forward or ship out aquatic species listed in CITES Appendices II and III if scientific assessments show that population of the species in the wild cannot remain viable under pressure of collection and trade. This means that all Manta spp. (M. birostris and $M$. alfredi) occurring in the country are automatically protected unless proven by scientific assessments that the existing stock of the species is sustainable even with existing pressure from harvest and trade. In a report on the rapid assessment of devil rays in Bohol Sea, Rayos et al. (2012) suggested that the area is a spawning ground for the said species and recommended habitat conservation and management measures. Moreover, they also recommended that a long-term stock assessment study be conducted since data is deficient to conclude on the status of the devil ray population.

In spite of the said laws, Manta spp. is still caught in drift gill net fishery in the Bohol Sea. Other mobulids remain unprotected except perhaps in the Province of Cebu where a local ordinance (No. 2014-15) was passed entitled "Amending Resolution No. 691-12/Ordinance No. 2012-05 also known as The Provincial Fisheries and Aquatic Resources Ordinance of Cebu". Under its Section $6,1-2$, it is stipulated that "it is unlawful to fish or take, possess, transport, deal, sell or in any manner dispose of any shark species not mentioned in this ordinance or its body parts such as but not limited to fins, tails, jaws, bladder." This local ordinance, at present, is not very clear on the scope of species protected and if it includes mobulids.

The fishery for mobulids in the Bohol Sea has been on-going since at least the nineteenth century (Acebes, 2013). With the mechanization of the fishery and the expansion of fishing grounds, there have been some indications of decline in catches in the Bohol Sea amidst increasing demand for mobulid ray meat and gill plates in local and international markets, respectively (Alava et al., 2002; Acebes, 2013). Initial studies point to Jagna and Pamilacan Island as the two primary mobulid ray fishery sites in the Bohol Sea (Acebes, 2013). Furthermore, previous studies on the fishery for mobulids in the Bohol Sea indicated that the mobulid ray fishery has expanded to new fishing grounds including the adjacent Surigao Strait (Acebes, 2013). According to local fishers in the region, the mobulids caught in the Surigao Strait are of a different type from that found in the Bohol Sea and occur in a different habitat. It is through the Bohol fishers' local knowledge on their marine resources that researchers were led to investigate on this different species of mobulid ray. Local ecological knowledge (LEK) of fishers has been recognized to have the potential to improve fishery management by providing information on the presence of species, their ecology, behavior, movement and other ecological processes that may influence their fishery resources (Azzurro et al., 2011; Johannes et al., 2000; Rasalato et al., 2010; Silvano and Valbo-Jørgensen, 2008). This study documented the fishers' LEK on Manta alfredi in a previously undescribed fishery and habitat in the Philippines.

$M$. alfredi has only been recently taxonomically resurrected (Marshall et al., 2009) and genetic studies using DNA microsatellites confirmed the existence of this second species of Manta (Kashiwagi et al., 2008; Ito and Kashiwagi, 2010). While there are several diagnostic differences, visually $M$. alfredi can be distinguished from $M$. birostris by the absence of the caudal spine encased in a calcified mass at the base of the tail, the "Y-shaped", white colouration pattern on the dorsal side of the animal, the absence of a continuous dark trailing edge on the ventral side, and the presence of dark spots on the ventral surface of the disc across the posterior half of the body and between the five adjacent gill slits (Marshall et al., 2009).

In the Philippines, the occurrence of $M$. alfredi has been listed by Marshall et al. (2009) and was verified through examination of photographs of animals observed in-water in the Tubbataha Reefs National Park (Aquino et al. 2013) and off Panaon Island, Southern Leyte (Verdote \& Ponzo 2014). The "manta bowl", off Ticao Island in Masbate is a known aggregation site for manta rays including the $M$. alfredi (Barr pers. comm.; Paylado, 2004; Walters, 2013). Monad shoal, off Malapascua Island in Cebu, is also an aggregation site for mantas, but only for $M$. birostris. However, there have been no tissue samples taken from any site in the Philippines to genetically verify the species.

DNA barcoding, a genetic method using the mitochondrial DNA CO1 gene to identify species, has been successfully utilized in the Philippines to establish first records of large marine vertebrate species including the rare Hotaula's beaked whale, Mesoplodon hotaula (Lacsamana et al., 2015) and the Pacific bluefin tuna, Thunnus orientalis (Sarmiento et al., 2016) as well as help solve issues in tuna catch documentation (Pedrosa-Gerasmio et al., 2012), seafood byproducts traceability (Maralit et al., 2013) and monitoring endangered marine species (Asis et al., 2014).

This study aimed to identify and describe the species of mobulids in a previously unknown area of occurrence in the Philippines. Through DNA barcoding of tissue samples from landed catch, we verified that the species targeted in this area off Dinagat Island is Manta alfredi. Our final objective was to characterize this habitat in order to contribute to the largely unknown biology and ecology of mobulids.

\section{Materials and methods}

The fishing village off Dinagat Island was first visited in June 2010 as part of the larger study of mobulid fisheries 
in the Bohol Sea. Semi-structured key informant interviews with fishers known to hunt for mobulid rays, locally known as "saranga", were conducted to determine the species targeted, fishing grounds, seasonality, and the technique of hunting. The fishers were asked to describe the animal they hunt, how they hunt them and what gear they use to hunt. The fishers were also asked to describe the location of their fishing grounds for mobulid rays, the seasonality of their fishing, the number of mobulid rays they catch, the distribution and market of their catch. Additional information regarding the origins of the fishery and livelihood sources of the fishers were also gathered.

The site was revisited in July 2014 to gather more information on the seasonality of the fishery, to verify the target species and to estimate the number of catches per season. A boat-based survey with the fishers was conducted to identify and mark the exact location of the ray fishing grounds.

The fishing site for mobulid rays was confirmed and is located at $\mathrm{N} 10^{\circ} 37.721^{\prime}$ and $\mathrm{E} 125^{\circ} 27.104$ ', several kilometers off Dinagat Island in the Surigao Strait (Fig. 1). The fishers accompanied the investigator to their fishing ground and demonstrated how they searched for mobulid rays. On the third field visit in 2014, the investigator was able to observe an actual hunt.

Landed mobulids were photographed and examined to determine the presence or absence of the three morphological diagnostic features of the two manta ray species. The base of the tail and coloration of the dorsal and ventral sides of the animal were examined. The sex of the animal was determined by examining the presence or absence of claspers. Tissue samples were collected from landed animals for genetic analysis. Samples of dried mobulid ray muscle and skin from previous catches were also collected for genetic analysis.

The site was again visited in August 2014 to conduct exploratory dives in the fishing sites in order to characterize it and search for the animals by deploying underwater video cameras. Due to camera loss the data could not be obtained. The habitat was characterized by visual observation, also noting the depth, speed and direction of the currents and taking underwater photographs of the sites.

Fishermen's description of the rays 'resting' raised suspicion of the site serving as a cleaning site, and so surveys were carried out in the mobulid fishing ground to locate potential cleaning stations that accommodate megafauna. Initial exploratory searches were done by hanging from the boats' outriggers while snorkeling and revealed two potential cleaning sites (See Table 1) that were then surveyed using SCUBA. As the site was previously uncharted, the team opted for a qualitative rather than quantitative approach, and so two 'expanding squares patterns', similar to those used in search and rescue scenarios, with a maximum leg length of $20 \mathrm{~m}$ (See Fig. 2) were carried out for half the bottom time (approximately 15 mins.) to maximizes the area covered. The remaining time was used to observe and describe the characteristics of the located cleaning stations.

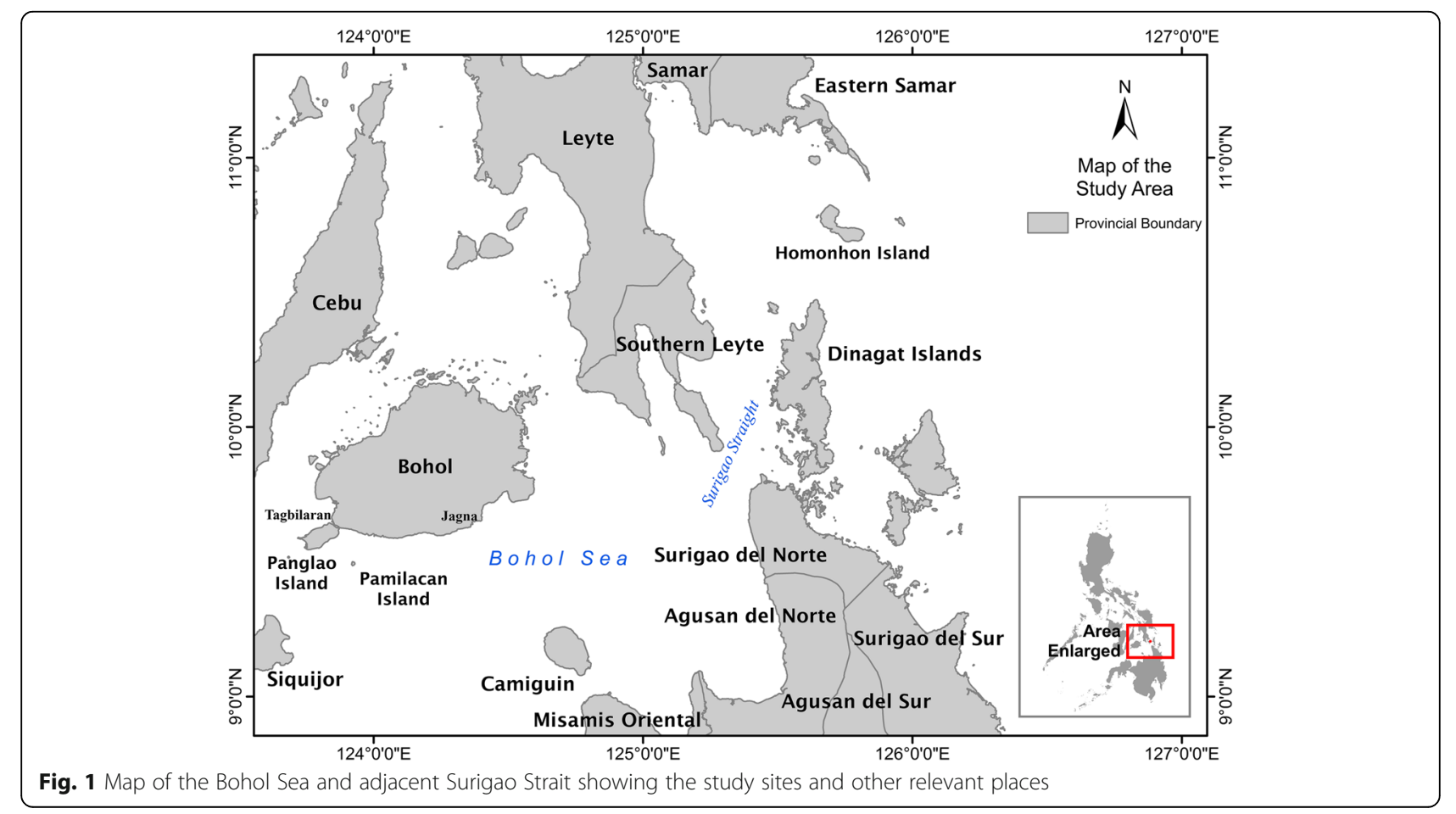


Table 1 Location and characterization of the dive sites within the fishing ground

\begin{tabular}{lll}
\hline Site name & Characteristics & Depth \\
\hline Dive site 1 (Tunga) & $\begin{array}{l}\text { Flat to sloping; relatively even seaweed cover; rocky reef with scattered massive } \\
\text { coral heads, barrel sponges; rocks covered with seaweed; inhabited by several } \\
\text { harems of Labroides dimidiatus (cleaner wrasses). }\end{array}$ \\
Dive site 2 (Tunga II) & $\begin{array}{l}\text { Flat; Sargassum patches or field of seaweeds with long stalks (3 m); substrate } \\
\text { is fine white gravel. }\end{array}$ \\
\hline
\end{tabular}

Dried and fresh mobulid ray tissue samples were preserved in a $70 \%$ ethanol. Genetic analysis through DNA barcoding was carried out by extracting the muscle tissue of the dried samples using Hotshot method described by Montero-Pau et al. (2008) wherein the samples were soaked in distilled water overnight, and the fresh sample using DNeasy Blood and Tissue Kit (Qiagen, Germany). Replicates of all samples were subjected to molecular species identification using mitochondrial DNA marker Cytochrome c oxidase I (MT-CO1) analysis. PCR cycling parameters used were as follows: Initial denaturation at $94{ }^{\circ} \mathrm{C}$ for $10 \mathrm{~min}$ followed by 35 cycles of denaturation at $94{ }^{\circ} \mathrm{C}$ for $1 \mathrm{~min}$, annealing at $50{ }^{\circ} \mathrm{C}$ for $1 \mathrm{~min}$, extension at $72^{\circ} \mathrm{C}$ for $1 \mathrm{~min}$, and finished by a final extension at $72{ }^{\circ} \mathrm{C}$ for 10 min. CO1 mitochondrial DNA marker with universal primers FishF2_Ward (5' - TCGACTAATCATAAAGAT ATCGGCAC - 3') and FishR1_Ward (5' - TAGACTT CTGGGTGGCCAAAGAATCA - 3') (Ward et al. 2005) were used for amplification. The amplified products generated 583, 549, and 650 base pairs fragment. Sequences were edited using Geneious 6.1.8, and were aligned and analyzed with MEGA 6 (Tamura et al. 2013). Analyses were performed using the Kimura 2-parameter model. All positions containing gaps and missing data were removed.

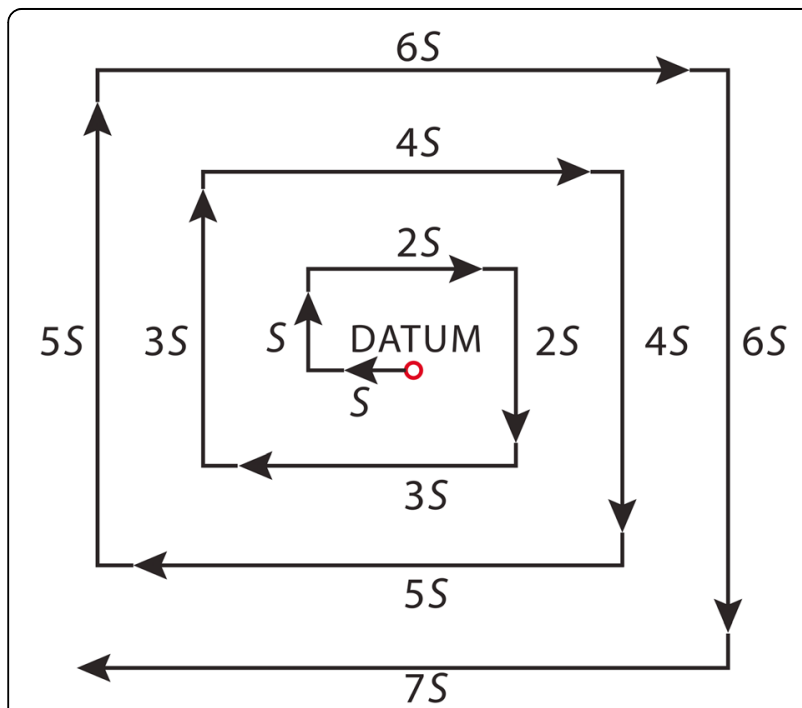

Fig. 2 Expanding Square search pattern. Surveys started at Datum, a $90^{\circ}$ turn was made at the end of each search leg (S). After two legs the swimming distance was increased by one Leg
Reference sequences of mobulid rays were obtained from GENBANK (http://www.ncbi.nlm.nih.gov/genbank).

\section{Results and discussion}

Four key informants were interviewed. All respondents were fishers and owners of a mobulid ray fishing boat. Informants identified their target species as "saranga", and distinguished it from the "sanga" or manta ray caught in Bohol. Informants described the "saranga" as black in color, with a disc width ranging from about 3 to $5 \mathrm{~m}$ wide, unlike the "sanga" of Bohol which has a "khaki-brown" color and grows to up to $8 \mathrm{~m}$ wide (Acebes 2013). The two are similar in the way that both have a white-colored pattern on its back. They added that the "sanga" of Bohol has thicker skin and has two round bumps at the base of the tail, similar to stones (Acebes 2013). The meat of the "saranga" is also considered of inferior quality compared to that of the "sanga". They distinguished "sanga" and "saranga" from mobula rays, locally known as "pantihan", as it is referred to in Bohol. According to the informants, "pantihan" are small and do not grow nearly as big as the "saranga". They also described it as having a "sharper" shape. Fishers occasionally catch mobula rays but because they swim near the surface, they do not use the harpoon but use the hook instead.

The interviews revealed that there are currently seven fishing boats for mobulids in the village with each boat having 5-8 crew members. A stainless steel toggle harpoon is used to catch the ray. The harpoon tip is $63.5 \mathrm{~cm}$ long which fits into a heavy metal handle about $3.6 \mathrm{~m}$ long, made from a steel pipe filled partly with cement. A thick nylon rope about six meters long is attached to the side of the harpoon tip. The technique of hunting is as described in Acebes (2013). Two to three boats cooperate in a hunt. One boat, usually smaller, serves as the hunting boat while the other is the mother boat or carrier boat. Each hunting boat can catch one manta ray per trip, but with a mother boat, it can unload its catch into the mother boat and resume hunting. Fishers set out at around 6 in the morning to their fishing ground which they refer to as "tunga" which means "in the middle" or "halfway". Fishers refer to this area as a shallow area as distinguished by the white sandy bottom. According to the fishers, the manta rays congregate on the sandy bottom on the top of the seamount which 
makes them easier to see from the surface. They described the manta rays as often seen "resting" on the seamount, barely moving. Once the fishers reach the seamount, they survey the area by lying on the outrigger of the boat and peering down into the water using goggles. Once a manta ray is spotted the boat approaches it slowly while the men hold steady the harpoon. The harpooner aims the harpoon towards the target and signals the drop. The weight of the harpoon buries the tip in the animal's back and the toggle secures it when it swims away. The rope attached to the harpoon tip is given out to let the animal tire itself out. When the animal is weakened the harpooner dives in the water to stab and kill it with a big knife. The animal is then cut up into at least four pieces and loaded unto the boat. A hunting boat accompanied by a mother boat may stay in the fishing grounds for the entire day to catch several manta rays. It is more common however, for the fishing trip to end by mid-day or the early afternoon. All catches are processed in the village. The meat, skin and gill plates are dried then transported and sold to buyers in Pamilacan Island in Bohol. Smaller pieces of meat and unwanted parts such as the tips of the pectoral fins and cephalic fins are consumed on the island. Fishers cover all their expenses for the delivery to Pamilacan Island. They cooperate by pooling their processed catches and sharing in the cost of transporting to Bohol. Considered of inferior quality compared to that of manta rays in Bohol, the products are bought by Boholano buyers for a much lower price (Acebes 2013). The dried meat \& skin derived from a large-sized manta ray with a disc width of $3 \mathrm{~m}$ can be sold for a total of 17,000 Philippine Pesos $(\mathrm{PhP})$ or US\$382.96 (PhP43.39=US\$ 1). Dried manta ray meat can be sold for PhP200-300 (US\$4.50-6.76) per kilo. The meat and skin are eaten and is a delicacy in Bohol. Dried gill plates are sold to middlemen in Bohol who sell it to Cebu. These can be sold for PhP3,0003600 (US\$67.58-81.09) per kilo. Fishers believe these are exported to China and South Korea for the Chinese medicine market. Although residents of the fishing village do not utilize the gill plates, according to key informants it is believed that it has medicinal properties which could treat kidney problems. Some also believe that eating manta ray products could prevent illness.

This fishery provides the supply of mobulid products to Bohol during the off-season for mobulid ray fisheries there. The mobulid fisheries season in Bohol begins as early as November and ends in May (Acebes, 2013). The mobulid ray fishing season in this area is from May to October. It is during this period that the mobulids are seen in the fishing ground. Fishers time their hunt with the phases of the moon, direction of the currents and ebb tides. Fishers go out 13 to 14 nights from the onset of the full moon to scout their fishing grounds. They believe that at new moon, when the tide is low and the currents are moving toward the Pacific, the manta rays come out. During the months of August and September, it is possible to go fishing for manta rays on the seventh night because in the morning, the direction of the current is southwest. Fishers believe that rays cannot be found in the fishing grounds when the outgoing tide and current is too strong coming from the Pacific. According to fishers, the number of catches varies considerably per season. During the 2014 season, fishers estimated that they caught a total of 100 "saranga" or manta rays from May until August. Fishers reported that in May 2014 one boat caught 12 and another eight; on 10 July 2014, they caught nine "saranga"; while on 21 August 2014, they caught five and on 7 September 2014, they caught two. In 2013 the same fishers reported not landing any manta rays. According to them during the 2012 and 2013 seasons, fishers reportedly sighted only a few animals in the fishing ground. One respondent claimed that several years ago he caught 18 manta rays in one day while another fisher caught 15 . However, in previous years, it is more typical to catch only three to four manta rays in one season.

The dive sites were located on a seamount with a depth of 32 to $33 \mathrm{~m}$ (See Table 1). The northern part was sloping down gradually while to the West there were seaweed patches. More than six territorial patches of Labroides dimidiatus were identified by examining aggression displays and retreats between adults. About a dozen Labroides dimidiatus cleaner wrasse were seen engaged in cleaning activity of semi-pleagic Jack fish (Family Carangidae) and Spangled Emperor Snapper (Lethrinus nebulosus). These interactions enabled to locate the focal point of two different cleaning stations (Potts, 1973). One focal point was a compound made of two adjacent rocks and the other a medium sized Porites coral head (Genus Porites). In other long-studied sites in the Philippines, such as Monad Shoal in Malapascua Island and Bontod Tacdogan near Ticao Island, focal points may exist at cleaning stations that tend to large clients, such as sharks and rays (Oliver et al. 2011; Oliver, current data; Barr, work in progress). The observed behavior of manta rays "resting" at the bottom of the sea floor reported by fishers is probably a hovering stance, associated with cleaning behavior (O'Shea et al., 2010; Jaine et al., 2012). No manta rays were observed during the dives however, two stingrays, one reef shark, and one nurse shark were spotted in the vicinity of the cleaning station. Based on observations, the fishing grounds for mobulid rays are located in a wide seamount approximately $22 \mathrm{kms}$ northeast from the fishing village in the Surigao Strait. Within this exact location are cleaning stations 
tending to semi-pelagic clients and where the presence of semi-pelagic and pelagic megafauna is frequently witnessed.

Two manta ray landings were witnessed, one on 12 July 2014 and another on 19 August 2014 (Figs. 3, 4, 5 and 6, respectively). Photographs were taken and disc width estimated. The animals were already partly cut up when landed. Based on the three morphological characteristics described in the methods section both animals resembled $M$. alfredi. The one caught in July was a pregnant female (fetus was kept by the fisher) while the one caught in August was an adult male with calcified claspers.

A total of nine tissue samples from mobulid ray catches were collected. Samples were taken randomly from dried ray meat from animals caught from the previous days. One of which was taken from the freshly caught manta ray on 19 August 2014.

CO1 gene from eight (8) out of nine tissue samples were successfully amplified and sequenced. Among the eight tissue samples, M8-2 sample was the freshly caught adult male manta ray on 19 August 2014 while, 6JMW sample was the dried sample from the pregnant female manta ray caught on 12 July 2014 . The samples $1 \mathrm{MWC}, 2 \mathrm{MWC}, 3 \mathrm{MWC}, 5 \mathrm{MWC}$, and $7 \mathrm{MWC}$ were dried manta rays caught within the month of July 2014; whereas 9MWC sample was from a manta ray caught on June 2010. The generated partial CO1 sequences with BOLD Process ID BFPHL119-16 (1MWC sample), BFPHL120-16 (2MWC sample), BFPHIL121-16 (3MWC sample), BFPHL122-16 (5MWC sample), BFPHL123-16 (7MWC sample), BFPHL116-15 (6MJW sample), BFPHL117-15 (M8-2 sample), and BFPHL118-16 (9MWC sample) showed $99.8 \%$ similarity to the published reference of $M$. alfredi in the BLAST search.

The tree generated was inferred using the Neighborjoining method and analyzed using Kimura-2 parameter

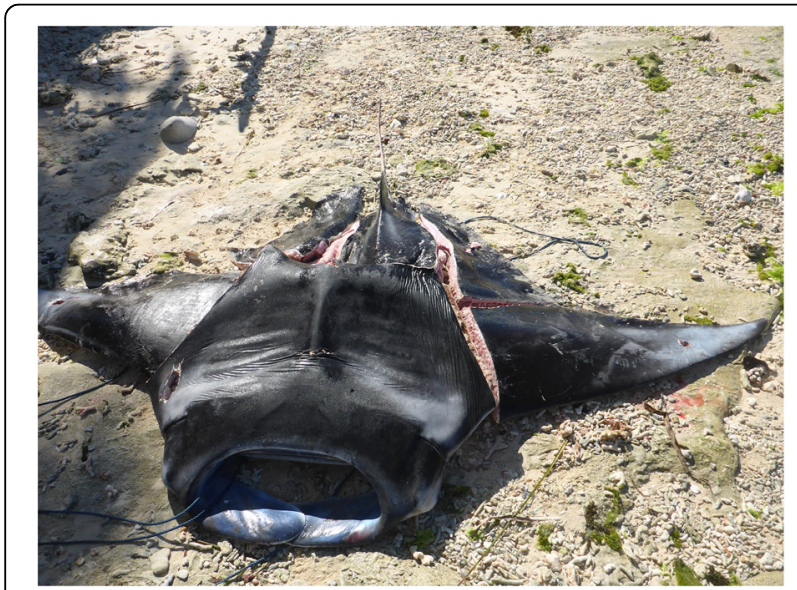

Fig. 3 Manta alfredi, pregnant female, caught on 12 July 2014

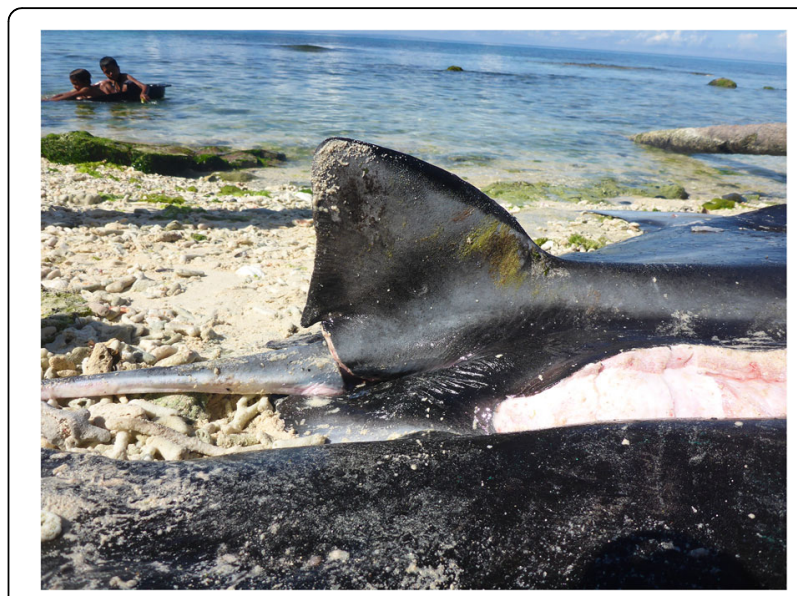

Fig. 4 Tail of the pregnant female Manta alfredi caught on 12 July 2014, showing the absence of the calcified mass

model. A $100 \%$ bootstrap value separated the clade where the three sequences clustered with the two reference $M$. alfredi to that of the M. birostris clade (Fig. 7). The COI analysis involved 24 nucleotide sequences with 484 positions each in the final dataset, and 85 parsimony informative sites. Genetic distances were also computed to support the identified species. The inferred identities of the eight mobulid ray samples have been validated through the 0.000-0.002 genetic distances with the two $M$. alfredi reference sequences (Fig. 8). This is the first record in BOLD and in GENBANK for $M$. alfredi found in the Philippines.

According to respondents, the fishery for mobulids in this village began in 2002 when a Boholano who lived in Surigao City visited the village after hearing reports of the abundance of manta rays in the area. He introduced the technique used today. The harpoon was designed based on the traditional toggle harpoon used in Jagna, Bohol (Acebes 2013). The Boholano had a monopoly of

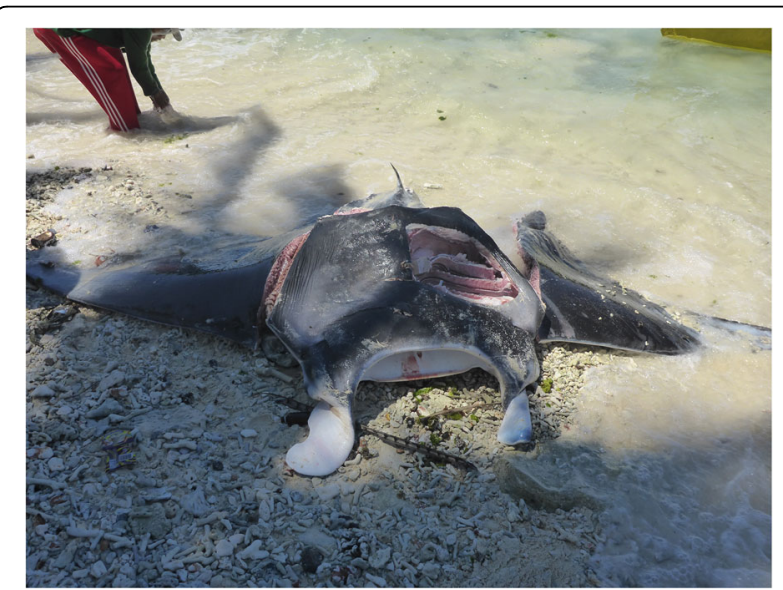

Fig. 5 Manta alfredi, adult male caught on 19 August 2014 


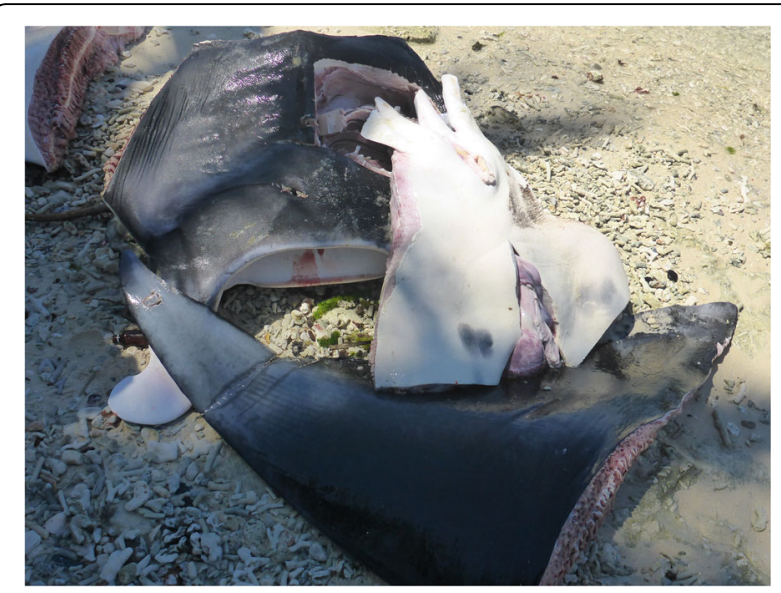

Fig. 6 Cut-up adult male Manta alfredi caught on 19 August 2014, showing the ventral pigmentation

the fishery by financing fishing trips and the market was in the Boholano community in Cagayan and in Bohol. There was a brief hiatus in the fishery due to local political conflict resulting in the Boholano closing his business. The fishery was revived about half a year later by an island local.

Based on key informant interviews, the fishers rely heavily on this fishery for their income. For most of the fishers and their families, this is their main source of livelihood. Based on the information from key informants regarding the cost of fishing and prices of manta ray products in 2014, it can be calculated that a fisher can earn at least PhP1,641 (US\$36.97) per average-sized manta ray caught. Hence, if one fisher caught 12 manta rays in one month, he could earn PhP19,700 (US\$443.79). This is considerable since the monthly basic minimum wage rate in 2014 was PhP8,850, given a daily minimum wage of PhP295-340. Although most of these fishers also engage in hook-and-line and net fishing for reef fish, it is not their primary source of income. The size and quantity of their catch is only suitable for family or village consumption. From the months of November until February when the cool northeast winds, locally known as "amihan" predominate, weather conditions do not allow for fishing hence, locals rely on any stocked dried fish, other produce bought from the mainland and a local root crop similar to yam as their staple. The island is not suitable for any other type of farming (i.e. rice, corn, vegetables).

Although the data presented here are preliminary and there is insufficient data to estimate the abundance of this population of the animals in this area, it can be said that a catch of over 100 animals per season in unlikely to be sustainable. As with most places in the world, no estimates are available for the manta ray population in the Philippines. However, the Manta alfredi population in the Ticao area surrounding Bontod Tacdogan seamount was estimated at between 141 and 201 individuals (Barr, work in progress). The largest population of M.alfredi estimated was in the Maldives, and the

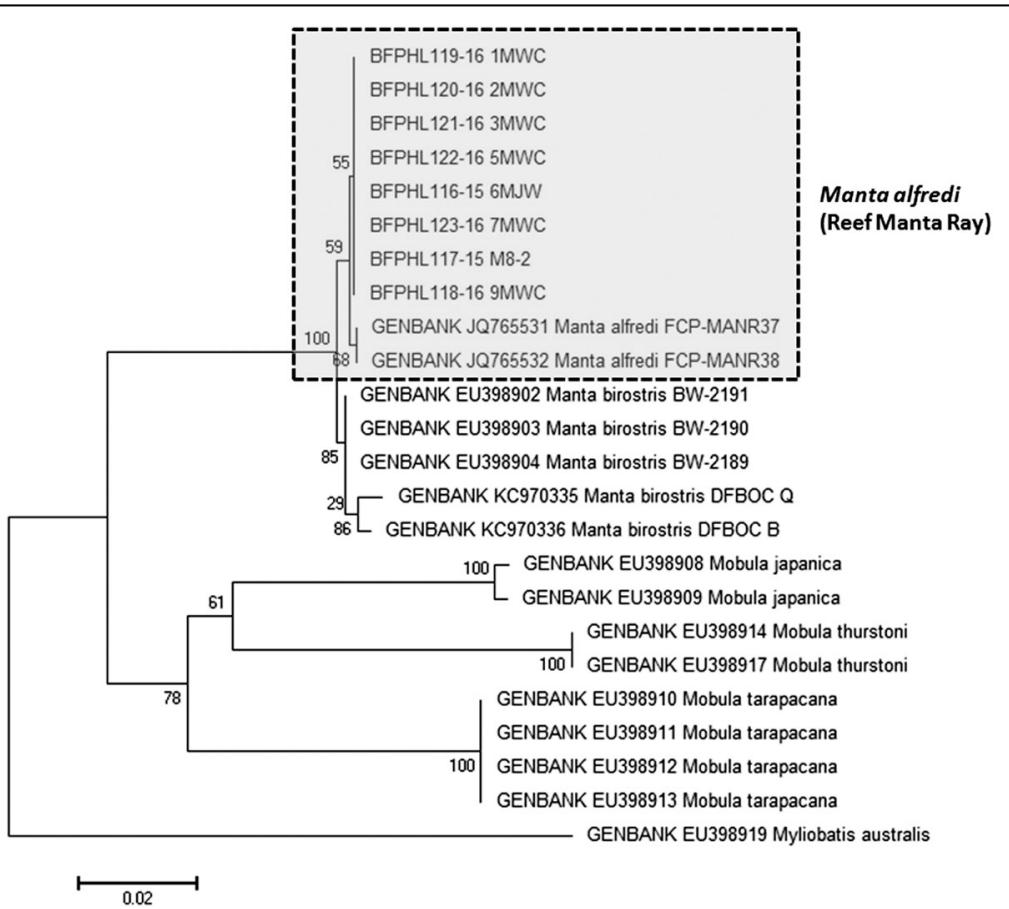

Fig. 7 Neighbor-Joining Tree of eight samples of mobulid rays CO1 sequences using Kimura 2-parameter model. Voucher sequences of Manta alfredi, Manta birostris, Mobula japanica, Mobula thurstoni, Mobula tarapacana and Myliobatis australis were included in the analysis 


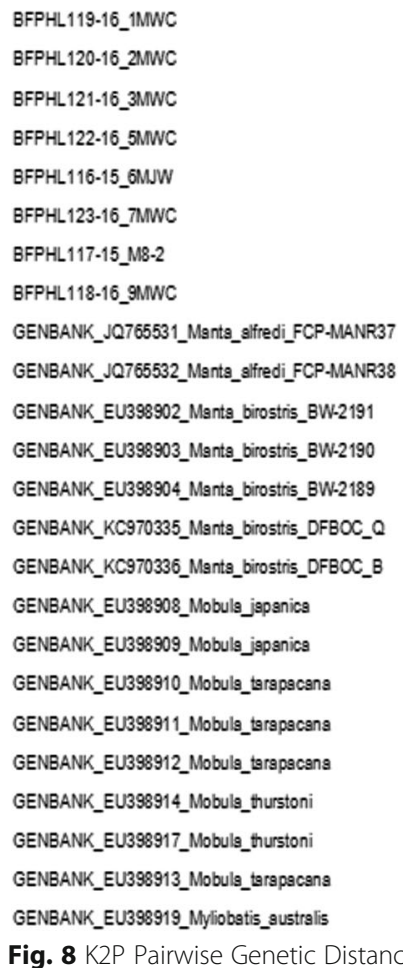

maximum number was 1468 individuals, while other estimates were much smaller, ranging between 200 and 800 (Marshall et al., 2011; Kitchen-Wheeler et al., 2012). Furthermore, $M$. alfredi is thought to live in local populations, which are susceptible to local anthropogenic threats (Deakos et al., 2011). This is demonstrated in the manta population in the Ticao area, where $39 \%$ of the mantas bore signs of injuries from anthropogenic origins, mostly from interactions with fishing gear (Barr, work in progress). Overexploitation of a local population could lead to its extirpation in that locality which could also have devastating effects on the communities that rely heavily on its fishery for their livelihood.

Based on morphological examination of caught animals, genetic analysis of tissue samples, and local fishers' ecological knowledge, the species targeted in this area in the Surigao Strait is the reef manta ray, M. alfredi. Other mobulids also occur in the area and are sometimes caught but these are not their target species. The fishing site exhibit the general characteristics of a cleaning station. There is a need for further characterization of manta rays' aggregation sites, such as cleaning stations in order to understand the ecology of this species.

The fishery is seasonal and there is extreme variability in the landings of mobulid rays with some seasons of no catch while on another season with up to 100 animals landed. The mobulid ray fishery in this village contributes significantly to the manta ray fishery in Pamilacan Island, Bohol because they serve as the supplier during the off-season in Bohol. Since the fishery serves as a significant source of income for the people in this fishing village recommendations on how to manage this fishery must take into consideration the socio-economic impact to this community. A socio-economic impact assessment on the fishing community is imperative.

It is imperative that the site is re-visited and further exploratory dives are conducted for a more detailed characterization of the underwater environment. Underwater video cameras should be deployed in order to confirm that the site previously identified is a cleaning station for manta rays. Video documentation could also be used to photographically identify the animals visiting the site in order to estimate the number of animals utilizing it. Furthermore, the value of fishers' LEK should not be underestimated in this case where very little data is available to scientists and fisheries managers. Followup interviews should be conducted to understand and verify the fishers' LEK on the seasonal and lunar variations in movement and abundance of the species. Documenting their LEK can also be used to reconstruct past catch landing numbers while actual catch landing monitoring within an entire season would provide better estimates of the catches.

This calls for the need to engage with the local community and open discussions to generate a better understanding on how their fishing activities are impacting on these species and the marine environment as a whole. Recognizing the fishers' contribution to the knowledge 
on the species and in enhancing the research will facilitate collaboration for designing an appropriate fisheries management strategy (Johannes, 1981; Silvano and Valbo-Jørgensen, 2008). Consultations and discussions with the fishing community are needed to determine how they can shift their target species. A suitable conservation action plan must be designed to address the possible overfishing of this species in the area.

\section{Acknowledgements \\ The authors wish to thank Medel Silvosa and the fishers of the village of Dinagat Province, in particular the Padul family. We thank Dr. Simon P. Oliver for his comments on the manuscript. We also thank Pierre Palallos for helping us with our figures and Leonard Soriano for making our map. Funding for this research was obtained from the Oak Foundation Mini-grants in Marine Conservation and support from the School of Science and Engineering of the Ateneo de Manila University as well as from the National Fisheries Research and Development Institute (NFRDI), Philippines and BALYENA.ORG. Funding and support of the manta ray ecology and behavior research in Ticao Island was granted through the Rufford Foundation (http://www.rufford.org), and executed under the supervision and guidance of Prof. A. Abelson of Tel-Aviv University in Israel.}

\section{Author details}

'BALYENA.ORG, Paseo del Mar, Barangay Pangdan, Jagna, Bohol 6308, Philippines. ${ }^{2}$ Department of Biology, Ateneo de Manila University, Loyola Heights, Quezon City, Philippines. ${ }^{3}$ Department of Zoology, Tel Aviv University, Ramat Aviv, Tel Aviv 69978, Israel. ${ }^{4}$ Genetic Fingerprinting Laboratory, National Fisheries Research and Development Institute, 101 Mo. Ignacia St., Quezon City 1103, Philippines.

\section{Received: 3 November 2016 Accepted: 4 November 2016}

Published online: 14 November 2016

\section{References}

Acebes JMV. Hunting 'Big Fish': A Marine Environmental History of a Contested Fishery. PhD thesis. Western Australia: Murdoch University; 2013.

Alava MNR, Dolumbal ERZ, Yaptinchay AA, Trono RB. Fishery and Trade of Whale Sharks (Rhincodon typus) and Manta Rays in the Bohol Sea, Philippines. In: Fowler SL, Reed TM, Dipper FQ, editors. Elasmobranch Biodiversity, Conservation and Management: Proceedings of the International Seminar and Workshop, Sabah, Malaysia, July 1997. Gland, Switzerland and Cambridge, UK: IUCN SSC Shark Specialist Group. IUCN; 2002. p. 132-48.

Alava MNR, Gaudiano JPA, Utzurrum JT, Capuli EE, Aquino MTR, Luchavez-Maypa MMA, Santos MD. Pating Ka Ba? An Identification Guide to Sharks, Batoids and Chimaeras of the Philippines. Department of Agriculture Bureau of Fisheries and Aquatic Resources - National Fisheries Research and Development Institute, Quezon City, Philippines and the Marine Wildlife Watch of the Philippines; 2015

Aquino MTR, Songco AM, Alarcon RC. Notes on the presence of Manta alfredi in the Tubbataha Reefs Natural Park, Cagayancillo, Palawan, Philippines; 2013. Paper presented at the 12th National Symposium in Marine Science (PAMS12), 24-26 October 2013, Tacloban City, Philippines.

Asis AMJM, Lacsamana JKM and Santos MD. Illegal trade of regulated and protected aquatic species in the Philippines detected by DNA barcoding. Mitochondrial DNA. 2014:1-8: doi:10.3109/19401736.2014.913138

Azzurro E, Moschella P, Maynou F. Tracking Signals of Change in Mediterranean Fish Diversity Based on Local Ecological Knowledge. PLOS ONE. 2011;6(9): e24885. doi:10.1371/journal.pone.0024885.

Bleeker P. Bijdrage tot de kennis der vischfauna van Nieuw-Guinea. Acta Societatis Regiae Scientiarium Indo-Neêrlandicae. 1859;6:1-24.

Couturier LIE, Marshall AD, Jaine FRA, Kashiwagi T, Pierce SJ, Townsend KA, Weeks SJ, Bennett MB, Richardson AJ. Biology, Ecology and Conservation of the Mobulidae. J Fish Biol, 2012;80:1075-119. doi:10.1111/j.1095-8649.2012. 03264.XPMID:22497374.

Deakos MH, Baker J, Bejder L. Characteristics of a manta ray (Manta alfredi) population off Maui, Hawaii, and implications for management. Mar Ecol Prog Ser. 2011;429:245-60.
Dolar LL. Incidental takes of small cetaceans in fisheries in Palawan, central Visayas and northern Mindanao in the Philippines, Report of the International Whaling Commission 15 (Special Issue), 355-363. 1994.

Ito T. Kashiwagi T. Morphological and genetic identification of two species of manta ray occuring in Japanese waters: Manta birostris and M. alfredi. Report of Japanese Society for Elasmobranch Studies. 2010; 46: 8-10.

Jaine FRA, Couturier LIE, Weeks SJ, Townsend KA, Bennett MB, Fiora K, Richardson AJ. When Giants Turn Up: Sighting Trends, Environmental Influences and Habitat Use of the Manta Ray Manta alfredi at a Coral Reef. PLoS ONE. 2012;7(10):e46170. doi:10.1371/journal.pone.0046170.

Johannes RE. Working with fishermen to improve coastal tropical fisheries and resource management. Bull Mar Sci. 1981;31:673-80.

Johannes RE, Freeman MMR, Hamilton RJ. Ignore fishers' knowledge and miss the boat. Fish Fish. 2000;1:257-71.

Kashiwagi T, Marshall A, Bennett M, Ovenden J. DNA evidence for cryptic species boundaries within Manta birostris? Abstracts of Joint Meeting of Ichthyologists and Herpetologists, Montreal, Quebec. 2008. p. 236

Kitchen-Wheeler A-M, Ari C, Edwards AJ. Population estimates of Alfred mantas (Manta alfredi) in central Maldives atolls: North Male, Ari and Baa. Environ Biol Fish. 2012;93(4):557-75.

Lacsamana JK, Ventolero MFH, Blatchley D, Santos MD. First record of a rare beaked whale Mesoplodon hotaula in the Philippines. Mar Biodivers Rec. 2015;8:e77. doi:10.1017/S1755267215000457.

Lloyd RE. On two species of eagle-rays with notes on the skull of the genus Ceratoptera. Records Indian Museum (Calcutta) 1908;2(2):175-180.

Manta with resurrection of Manta alfredi (Krefft, 1868) (Chondrichthyes: Myliobatoidei; Mobulidae). Zootaxa. 2301:1-28.

Maralit BA, Aguila RD, Ventolero MFH, Perez SKL, Santos MD. Detection of mislabeled commercial fishery by-products in the Philippines using DNA barcodes and its implications to food traceability and safety. Food Control. 2013;33:119-25.

Marshall AD, Compagno LVV, Bennett MB. Redescription of the genus. 2009

Marshall AD, Dudgeon CL, Bennett MB. Size and structure of a photographically identified population of manta rays Manta alfredi in southern Mozambique. Mar Biol. 2011;158(5):1111-24.

Montero-Pau J, Gómez A, Muñoz J. Application of an inexpensive and highthroughput genomic DNA extraction method for the molecular ecology of zooplanktonic diapausing eggs. Limnol Oceanogr Methods. 2008;6:218-22.

Müller, J. \& Henle, F.G.J. Systematische Beschreibung der Plagiostomen. Berlin, 1841. pp. 187.

O'Shea OR, Kingsford MJ, Seymour J. Tide-related periodicity of manta rays and sharks to cleaning stations on a coral reef. Mar Freshw Res. 2010; 61(1):65-73.

Oliver SP, Hussey NE, Tumer JR, Beckett AJ. Oceanic Sharks Clean at Coastal Seamount. PLoS ONE. 2011;6(3):e14755. doi:10.1371/journal.pone.0014755.

Paylado TC. (2004) The Giant Manta Rays (Manta birostris, Bancroft 1829) Habitat in Bontod-Tacdogan Reef, San Jacinto, Masbate. Paper Presented during the 8th Zonal R\&D Review, DLSU, Taft Ave, Metro Manila, October 6-7, 2004

Pedrosa-Gerasmio IR, Babaran RP, Santos MD. Discrimination of juvenile yellowfin (Thunnus albacares) and bigeye (T. obesus) tunas using mitochondrial DNA control region and liver morphology. PLoS ONE. 2012;7(4):e35604. doi:10.1371/journal.pone.0035604.

Philippi RA. Algunos peces de Chile. Anales del Museo Nacional de Chile, Seccion 1, Zoologica. 1892;3:1-17.

Potts GW. The ethology of Labroides dimidiatus (Cuv. \& Val.) (Labridae, Pisces) on Aldabra. Anim Behav. 1973;21(2):250-91.

Rasalato E, Maginnity V, Brunnschweiler JM. Using local ecological knowledge to identify shark river habitats in Fiji (South Pacific). Environ Conserv. 2010;37(1): 90-7. doi:10.1017/S0376892910000317.

Rayos JCC, Santos MD, Barut NC. Status of devil ray resources in Bohol Sea, Philippines. Fish for the People. A Special Publication for the Promotion of Sustainable Fisheries for Food Security in the ASEAN Region. Bangkok, Thailand; 2012. ISSN: 1685-6546. Vol. 10, No. 1, pp. 20-23.

Sarmiento K, Ventolero MM, Ramiscal R, Dela Cruz W, Santos MD. First DNA record of Pacific bluefin tuna, Thunnus orientalis in Philippine waters. Mar Biodivers Rec. 2016;9:25. doi:10.1186/s41200-016-0020-y.

Silvano RAM, Valbo-Jørgensen J. Beyond fishermen's tales: contributions of fishers' local ecological knowledge to fish ecology and fisheries management. Environ Dev Sustain. 2008;10:657-75. doi:10.1007/s10668-008-9149-0.

Tamura K, Stecher G, Peterson D, Filipski A, Kumar S. MEGA6: Molecular Evolutionary Genetics Analysis Version 6.0. Mol Biol Evol. 2013;30:2725-9. 
Verdote DMM, Ponzo A. First record of Manta alfredi in the Bohol Sea. 2014. Philippines. Poster presented at the Shark International, (http://www.lamave. org/wp-content/uploads/2014/11/Ponzo_A.First-Record-of-Manta-Alfredi-inthe-Bohol-Sea.pdf).

Walbaum JJ. Petri artedi sueci genera piscium. Grypeswaldiae: A. F. Rose. 1792. Walter JMH. The Behaviour of Pygmy Devil Rays (Mobula eregoodootenkee) in response to cleaning interactions at Monad Shoal, Philippines. MSc thesis. U.K. University of Southampton; 2013.

Ward RD, Zemlak TS, Innes BH, Last PR, Hebert PD. DNA barcoding Australia's fish species. Philos Trans R Soc Lond B Biol Sci. 2005;360(1462):1847-57.

Submit your next manuscript to BioMed Central and we will help you at every step:

- We accept pre-submission inquiries

- Our selector tool helps you to find the most relevant journal

- We provide round the clock customer support

- Convenient online submission

- Thorough peer review

- Inclusion in PubMed and all major indexing services

- Maximum visibility for your research

Submit your manuscript at www.biomedcentral.com/submit 